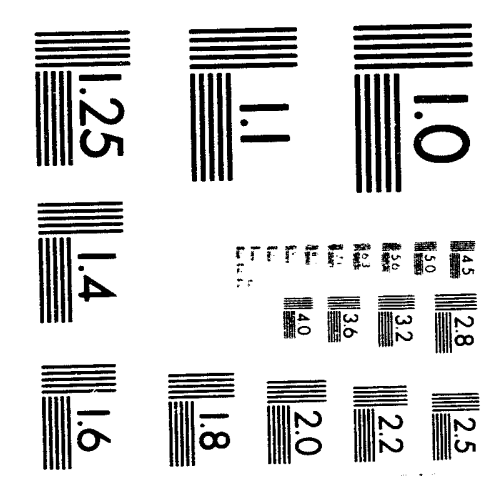



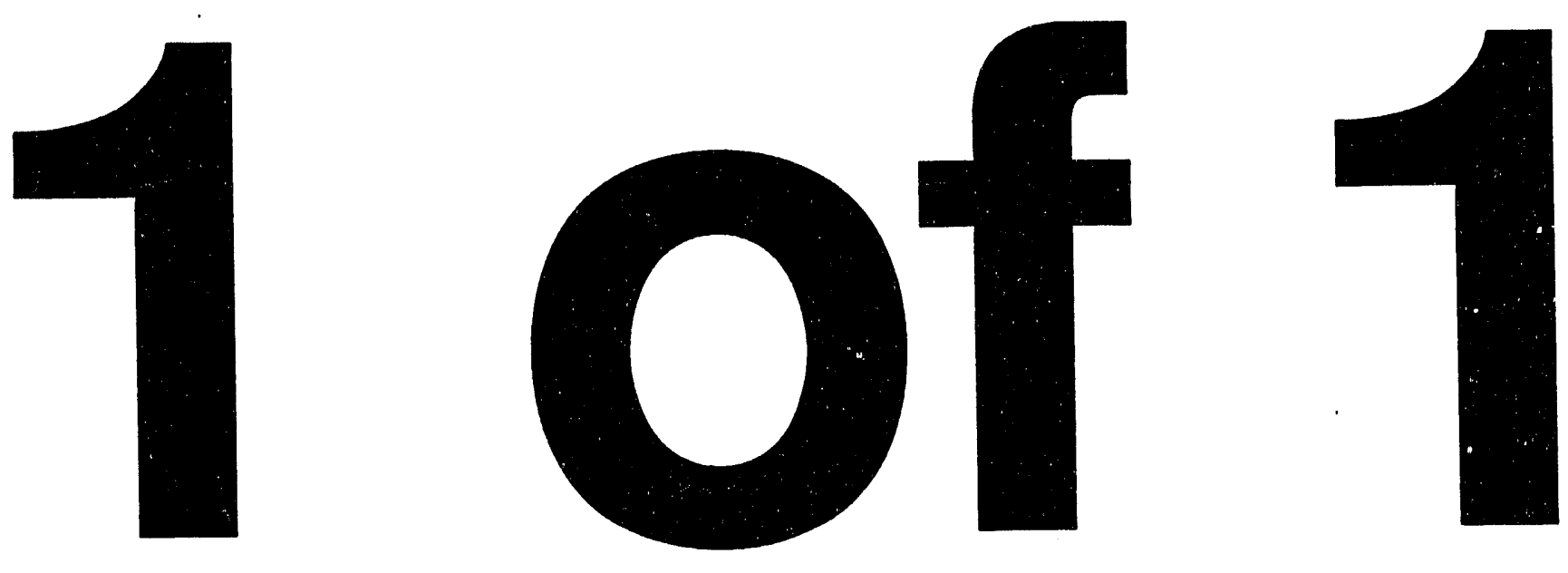


\title{
DXE/ER/1416S-TT
}

\section{The Formation of Silica, Alumina and Zirconia Supported High Surface Area Monometallic and Bimetallic Catalysts}

\section{By}

\author{
Richard D. Gonzalez
}

Department of Chemical Engineering, Tulane University, New Orleans, LA 70118.

\section{Progress Report}

During the current granting period, 12/01/92-11/30/93, studies have progressed along four fronts (1-4) : (1) Preparation of high surface area $\mathrm{Pu} / \mathrm{SiO}_{2}$ catalysts; (2) preparation of high surface area $\mathrm{Pt}_{\mathrm{A}} \mathrm{I}_{2} \mathrm{O}_{3}$ catalysts; (3) preparation of high surface area promoted zirconia superacid catalysts and, (4) stabilization and sintering of porous $\mathrm{Pt} / \mathrm{SiO}_{2}$ catalysts. In addition to these current studies a major review article on previously funded DOE research has been completed and will appear in Catalysis Review's (5). The results of these studies are briefly described below.

\section{The Preparation of High Surface Area $\mathrm{Pt} / \mathrm{SiO}_{2}$ Catalysts}

Conclusions from this study are as follow's (2-3): (1) Variables which control the microstructure of silica prepared by the sol-gel method using tetraethoxysilane as the silica precursor include: preparative $\mathrm{pH}$, reactant stoichiometries and gelation temperature. High surface areas and well-defined pore diameters can be obtained using sol-gel processing. In particular, surface areas as high as $1000 \mathrm{~m}^{2} / \mathrm{g}$ with microporous structures can be prepared at low $\mathrm{pH}$ (1.3). At intermediate values of the $\mathrm{pH}(3-8)$, BET surface areas ranging from 850 to $350 \mathrm{~m}^{2} / \mathrm{g}$ can be obtained. Pore structures are mesoporous with pore diameters ranging from 4 to $25 \mathrm{~nm}$ at a preparative $\mathrm{H}_{2} \mathrm{O} / \mathrm{TEOS}$ ratio of 10 . (2) Because of repulsive interactions, the use of $\mathrm{H}_{2} \mathrm{PiCl}_{6} \times \mathrm{X} \mathrm{H}_{2} \mathrm{O}$ as the metal precursur results in poor dispersions. When $\mathrm{Pt}\left(\mathrm{NH}_{3}\right)_{4}\left(\mathrm{NO}_{3}\right)_{2}$ is used, the precursor-support interactions become attractive and high dispersions are obtained. However, BET surface areas and pore volumes are difficult to control. The use of $\mathrm{Pt}(\mathrm{ACAc})_{2}$ was found to be the most flexible metal precursor. Solubility in acetone is high, and surface areas and pore volumes are more easily controlled. (3) Solvent extraction under supercritical conditions lead to high BET surface areas and large pore volumes. However, metal dispersions are unsatisfactory: 


\section{DISCLmaLR}

This report was prepared as an account of work sponsored by an agency of the United States Government. Neither the United States Government nor any agency thereof, nor any of their employees, makes any warranty, express or implied, or assumes any legal liability or responsibility for the accuracy, completeness, or usefulness of any information, apparatus, product, or process disclosed, or represents that its use would not infringe privately owned rights. Reference herein to any specific commercial product, process, or service by trade name, trademark, manufacturer, or otherwise does not necessarily constitute or imply its endorsement, recommendation, or favoring by the United States Government or any agency thereor. The views and opinions of authors expressed herein do not necessarily state or reflect those of the United States Government or any agency thereof. 
$\mathrm{Pt} / \mathrm{SiO}_{2}$ catalysts prepared by the sol-gel method were found to be at least as active in $\mathrm{H}_{2} / \mathrm{n}$-hexane reforming reactions as catalysts prepared by traditional ion-exchange methods. In addition to this high catalytic activity, these catalysts were found to be resistant to catalyst deactivation due to coke formation. They were also found to be more resistant to sintering than catalysts prepared by ion-exchange and impregnation methods.

\section{The Preparation of High Surface Area $\mathrm{Pt}_{/} \mathrm{Al}_{2} \mathrm{O}_{3}$ Catalysts}

Major conclusions from this study are as follows:

(1) $\mathrm{Pt} / \mathrm{Al}_{2} \mathrm{O}_{3}$ catalysts prepared by the sol-gel method using aluminum tertiary butoxide (ATB) as a starting material, result in high surface area materials (4). Surface areas in excess of $800 \mathrm{~m}^{2} / \mathrm{g}$ can be obtained. However, heat trcatment at $600{ }^{\circ} \mathrm{C}$ results in a reduction in the surface area to $400 \mathrm{~m}^{2} / \mathrm{g}$ due to the formation of the $\gamma$-alumina phase.

(2) A stoichiometric molar ratio of $\mathrm{H}_{2} \mathrm{O} / \mathrm{ATB}$ of 3 was found to be optimum in the preparation of highly dispersed $\mathrm{Pu}_{\mathrm{A}} \mathrm{I}_{2} \mathrm{O}_{3}$ catalysts.

(3) A mixed metal oxide sample prepared by prehydrolyzing and then mixing 5 wt \% silica with alumina resulted in a larger and more stable surface area than pure alumina.

(4) The use of $\mathrm{H}_{2} \mathrm{PtCl}_{6} \cdot \mathrm{xH}_{2} \mathrm{O}$ as a metal precursor was found to lead to highly dispersed $\mathrm{Pt}_{\mathrm{A}} \mathrm{I}_{2} \mathrm{O}_{3}$ catalysts. These catalysts were obsened to be active for the $\mathrm{H}_{2} / \mathrm{n}$-hexane reaction.

\section{The Stabilization and Sintering of Porous $\mathrm{Pt} / \mathrm{SiO}_{2}$}

It was found that when the average metal particle size was matched to the average pore size, sintering in flowing $\mathrm{O}_{2}$ at $675^{\circ} \mathrm{C}$ for $72 \mathrm{~h}$ had little effect on particle size (1). However, if the wt \% loading was higher than 0.2-0.3 wt \%, some sintering did occur. This resistance to sintering is in marked contrast to catalysts prepared by ion-exchange or impregnation for which rapid sintering was observed at temperatures in excess of $600^{\circ} \mathrm{C}$. These observations are consistent with previous studies using $\mathrm{Ru}$ and suggest that the preparation of supported metal catalysts by the sol-gel method can be structured to prepare materials which have a high degree of thermal stability. 


\section{The Preparation of High Surface Area Zirconia Catalysts}

High surface area zirconia catalysts were prepared by the sol-gel method using zirconium tetra isopropoxide ( $\mathrm{ZrT}$-iP) as the starting material. Although the results obtained are still preliminary, the following conclusions are emerging:

(1) High $\mathrm{H}_{2} \mathrm{O} / / \mathrm{ZrT}$-iP lead to surface areas in excess of $200 \mathrm{~m}^{2} / \mathrm{g}$. However, a considerable loss in surface area occurs following heating at temperatures in excess of $400^{\circ} \mathrm{C}$. Calcination at $200^{\circ} \mathrm{C}$ results in materials with a surface area of $370 \mathrm{~m} 2 / \mathrm{g}$. When the temperature was increased to $500^{\circ} \mathrm{C}$ the surface area was observed to decrease to 160 $\mathrm{m}^{2} / \mathrm{g}$.

(2) The preparation of uixed zirconium-titanium oxides resulted in materials having not only a higher surface area than zirconium or titania, but also materials with a much higher thermal stability.

(3) A maximum surface area was observed for the mixed $\mathrm{Zr}$-Ti oxide for which the molar ratio of $\mathrm{ZrT}$-iP/TiT-iP was unity. Calcination temperatures in excess of $500^{\circ} \mathrm{C}$ were required to markedly reduce the surface area.

(4) The zirconia and the mixed Zirconia-Titania oxides were promoted using both $\mathrm{H}_{2} \mathrm{SO}_{4}$ and $(\mathrm{NH} 3)_{2} \mathrm{SO}_{4}$. Surface areas appear to be slightly low'er when $(\mathrm{NH} 3)_{2} \mathrm{SO}_{4}$ is used. The superacid properties of these materials will be studied during the next funding period.

\section{Outline for studies to be Completed During the Nex Funding Period}

\section{Continuing Studies on the Preparation of $\mathrm{Pt} / \mathrm{Al}_{2} \mathrm{O}_{3}$ Catalysts}

Studies to date have been focussed on preparative variables aimed at maximizing BET surface areas and metal dispersions. These studies have been completed and the activity of the resulting materials compare favorably with $\mathrm{PUAl}_{2} \mathrm{O}_{3}$ catalysts prepared by ionexchanged and impregnation methods. However, attempts to compare the catalytic properties of $\mathrm{PtAl}_{2} \mathrm{O}_{3}$ catalysts prepared by the sol-gel method to commercial reforming catalysts is sort of like comparing apples to oranges. To make valid comparisons we will need to chlorinate the $\mathrm{PuAl}_{2} \mathrm{O}_{3}$ sol-gel catalysts in order to modify the acid properties of the support. Sulfiding of the resultant catalysts is also a necessary step. We have recently initiated such studies in order to make valid comparisons. The addition of a second metal (i,e., Ir, Sn or Re) is also under study. 
Attempts to ion-exchange or impregnate metals on large surface area arerogels or xerogels has not been very successful. In general rather poor metal dispersions were obtained using this approach. In order to understand why this is so an infrared study of the resuiting aerogels and xerogels will be performed. What I suspect is happening is that the surface hydroxyl groups are undergoing esterification by solvent molecules and inhibiting the ionexchange process. If this can be reversed, a second method of preparing high surface area supported metals with high dispersions may result.

\section{Continuing Studies on the Preparation of $\mathrm{Pt} / \mathrm{SiO}_{2}$ Catalysts}

Comments similar to those made for the preparation of $\mathrm{PtAl}_{2} \mathrm{O}_{3}$ catalysts by the sol-gel method also apply to $\mathrm{SiO}_{2}$ catalysts. In other words high surface area aerogels and xerogels can be impregnated or ion-exchanged using either organic or inorganic metal precursors with difficulty. Hopcfully, this matter can be resolved by performing an infrared study:

The sharp dependence of metal dispersion on precursor is puzzling. $\mathrm{H}_{2} \mathrm{PtCl}_{6} \cdot \mathrm{xH}_{2} \mathrm{O}$ and $\mathrm{Pt}\left(\mathrm{NH}_{3}\right)_{4} \mathrm{Cl}_{2}$ have been disappointing. However, the use of $\mathrm{Pt}\left(\mathrm{NH}_{3}\right)_{4}\left(\mathrm{NO}_{3}\right)_{2}$ resulted in high dispersions. $\operatorname{Pt}(A C A C)_{2}$ is also acceptable and has an advantage over $\mathrm{Pt}\left(\mathrm{NH}_{3}\right)_{4}\left(\mathrm{NO}_{3}\right)_{2}$ in that its solubility in acetone is higher. We suspect that the problem that we have encountered may be due to the presence of chloride. We plan to undertake a study of the adsorbed species using diffuse UV reflectance spectroscopy. Interference of the resuliant UV spectra due to silica bands and solvent molecules has been troublesome in the past. However, new subtractive sof ware which we have recently installed will alleviate the problem. Care must be taken in the interpretation of spectral results.

A significant new finding in our current studies is the observation that when the metal particle size is matched to the pore diameter, a high degree of thermal stability is achieved. Unfortunately this thermal stability' can only be achieved for rather low loadings $(<0.4 \mathrm{wt}$ \%). We most certainly want to pursue this observation. High thermal stability of supported metals in such applications as automotive exhaust catalysts are badly needed. An extension of our Pt studies to include $\mathrm{Rh}, \mathrm{Ru}$ and $\mathrm{Pd}$ is planned.

\section{Continuing Studies on High Area Superacid Catalysts}

We regard our current obser ations on the thermal stability of sulfate promoted $\mathrm{Zr}$-Ti oxide catalysts to be very encouraging. Because superacidity is very difficult to measure with solid indicators, we are approaching the problem using an infrared study combined with a 
catalytic study using the isomerization of $\mathrm{n}$-butane as a probe rcaction.

As shown in Figure 1, the adsorption of pyridine results in a change in the bond order of both the $\mathrm{S}-\mathrm{O}$ and the $\mathrm{S}=\mathrm{O}$ bond. For $\mathrm{M}=\mathrm{Zr}$ or $\mathrm{Ti}$, the shift in the position of the $\mathrm{S}=\mathrm{O}$ bond following the adsorption of pyridine is $50 \mathrm{~cm}-1$. For $\mathrm{M}=\mathrm{Fe}$, the shift is $46 \mathrm{~cm}-1$ and for $\mathrm{M}=\mathrm{Al}$ it is $33 \mathrm{~cm}-1$. For $\mathrm{M}=\mathrm{Si}$ or $\mathrm{Bi}$, no shift is observed. Perhaps the $\mathrm{S}=\mathrm{O}$ bond shift can be related to the superacid properties obtained by measuring $n$-butane isomerization rates.

\section{Personnel}

The current level is appropriate. Two graduate students will be supported. Additionally, two undergradua:e students will perform honors research during the academic year and will be incorporated into the group during the Summer. Each undergraduate will receive a summer stipend of $\$ 3,000$. It is anticipated that this research experience will be of value to them.

\section{Budget}

It is anticipated that the funds originally set aside for this project will be satisfactory. A second gas chromatograph which is essential to our catalytic studies will be added with funds supplied by a DOE supplement.

\section{Equipment}

The current inventory in the Catalysis laboratory includes:

A Coulter Omnisorb Gas Sorption Analyzer.

A Coulter Delfsa instrument to perform zeta potential measurements

A Digilab FT 40 FTIR

An on-line Balzer's quadrupole mass spectrometer

A Perkin Elmer UV visible spectrophotometer interfaced to a remote integrating sphere through fiber optics cables

A Perkin Elmer Differential Scanning Calorimeter

Three on-line reaction systems for performing catalytic studies

Two Hewlett Packard gas chromatographs

Access to a scanning transmission electron microscope and an ICP is available. 
* Proposed Structure of sulfur-promoted metal oxiries

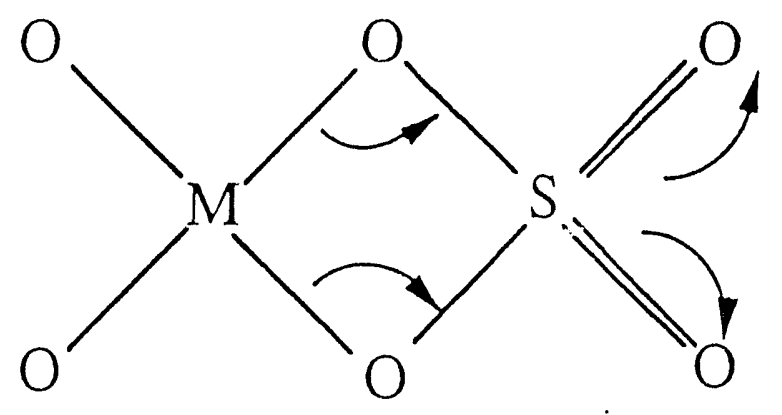

$: \mathrm{S}=\mathrm{O}$ streching frequency shift by pyridine adsorption

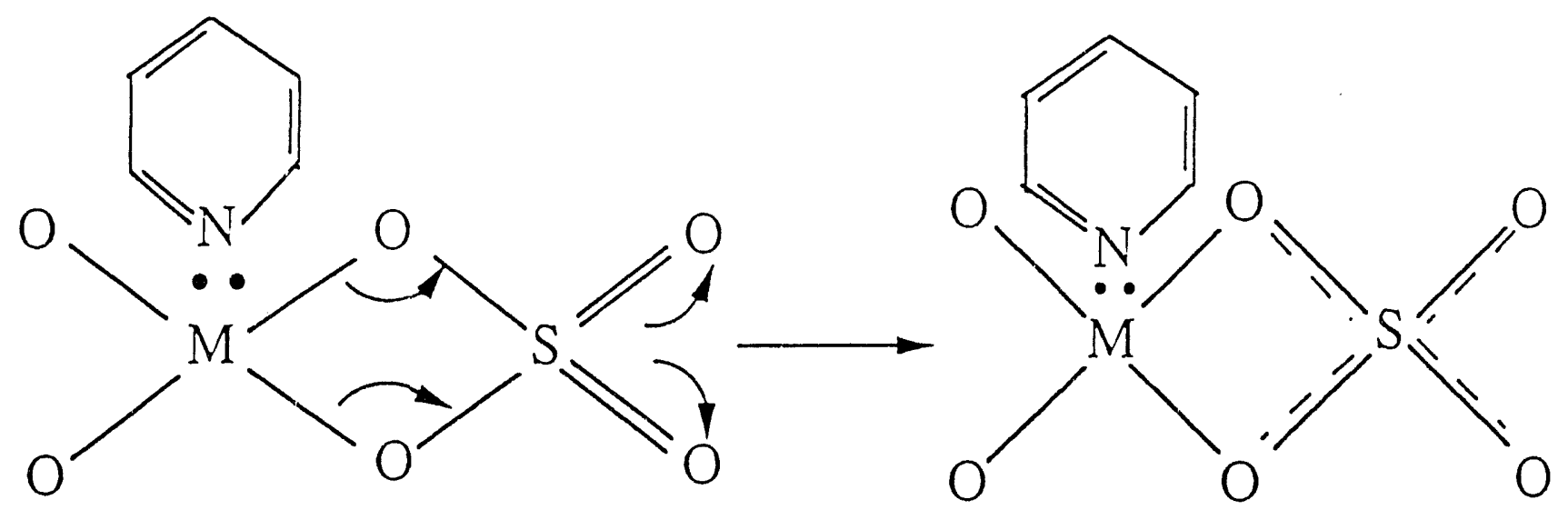

Figure 1 


\section{References}

1 Strong Inhibition to Sintering and Deactivation of $\mathrm{Pt} / \mathrm{SiO}_{2}$ Catalysts Prepared by the Sol-Gel Method. With Weiqing Zou. Journal of Applied Catalysis, In Press

2 The Preparation of High Surface Area $\mathrm{P} / \mathrm{SiO}_{2}$ Catalysts with Well-Defined Pore Size Distributions: Gelation Chemistry of Blank Silica and Supported $\mathrm{Pt}$ Catalysts. With Weiging Zou. Submitted to the Journal of Catalysis.

$3 \mathrm{Pt} / \mathrm{SiO}_{2}$ Xerogels and Aerogels as Reforming Catalysts: A Comparison of their Catalytic Properties in the $\mathrm{H}_{2} / \mathrm{n}$-hexane Reaction. With Weiqing Zou. Submitted to the Journal of Catalysis.

4 Preparation of Pt/Alumina Catalysyts by the Sol-Gel Method. With K. Balakrishnan. Journal of Catalysis. In Press

5 Preparation of $\mathrm{SiO}_{2}$ and $\mathrm{Al}_{2} \mathrm{O}_{3}$ Supported Clusters of $\mathrm{Ft}$ Group Metals With H. Miura. In Press, Catalysis Reviews.

\section{Publications Under DOE Sponsorship}

1. Oxidation of Ethanol on Silica Supported Noble Metal and Bimetallic Clusters, by R.D.Gonzalez and M. Nagai, J. Appl. Catal. 18, $57-70$ (1985).

2. Precursor-Support Interactions and their Effect on the Surface Composition of Bimetallic Clusters, by H. Miura, S.S. Feng, R. Saymeh and R.D. Gonzalez. A.C.S. Symposium Series 288, 25, 294-304 (1985).

3. An Improved Infrared Cell-Reactor for Use in Transient Response Studies. The Catalytic Oxidation of CO Reexamined, by M. Nagai, L.L. Lucietto and R.D. Gonzalez. J. Catal. 101, 522-526 (1986).

4. The Effect of Reduction Temperature on the Chemisorptive Properties of $\mathrm{Ru} / \mathrm{Al}_{2} \mathrm{O}_{3}$ : Effect of Chlorine. T. Narita, H. Miura, M. Ohira, K Sugiyama, T. Matsuda and R.D. Gonzalez. J. Appl. Catal. 32, 185-190 (1987).

5. The Effect of Pretreatment on the Surface Composition of Supported Pt-Ru Bimetallic Clusters. M. Asomoza, G. del Angcl, R. Gomcz, B. Rejai, and R.D. Gonzalez. Proc. IX Int Cong Catal, Editors, M.J. Phillips and M. Ternan. Vol. 3, 1182-1190 (1988). 
- Calgary Canada.

6. The Role of Preparative Variables on the Surface Composition ofSupported Pt-Ru Bimetallic Catalysts. S. Alerasool, D. Boecker, B. Rejai,R.D. Gonzalez, G. del Angel, M. Asomoza and R. Gomez. Langmuir 4, 5,1083-1090 (1988).

7. The Effect of Residual Chlorine on the Adsorptive and Catalytic. Propertiesof Supported Noble Metal catalysts. H. Miura, N. Hondou, K. Sugiyama,T. Matsuda and R.D. Gonzalez. Proc IX Int Cong Catal, Editors, M.J.Phillips and M. Ternan. Vol. 3, 1307-1313 (1988). Calgary, Canada.

8 Surface Composition of Pt-Ru catalysts: Effect of the Support. G. del Angel, C. Medina, R. Gomez, B. Rejai and R.D. Gonzalez. Calalysis Today 5, 395-401 (1989).

9. The Formation of Supported Bimetallic Cataly'sts: I. The Measurement of Enthalpies of Gas-Solid Reactions Using Differential ScanningCalorimetry. B. Rejai and R.D. Gonzalez. J. Catal. 123, 98-112 (1990)

10. The Formation of Supported Bimetallic Catalysts II: The Application of a Quantitative DSC technique. B Rejai and R.D. Gonzalez. J. Catal. 123, 113-129 (1990)

11. Chemical Analysis of small Pt-Ru Bimetallic Particles by EDS. G. del Angel, J.M. Dominguez, R. Gomez, S. Alerasool, and R.D. Gonzalez. Surface Science 224, 407-424 (1989).

12. The Control of Metal Precursor Mobilitics as a Variable in the Preparation of Supported Pt-Ru Bimetallic Clusters: The Use of Ruthenocene. WithH. Miura, H. Tagushi, K. Sugiyama andT. Matsuda. J. Catal. 124, 194203 (1990).

13. Preparation and Characterization of Supported Pt-Ru Bimetallic Clusters: Strong Precursor-Support Interactions, with S. Alerasool. J. Catal. 124, 204-216 (1990)

14. Variables Which Affect the Formation of Supported Pt-Ru Bimetallic Clusters. With H. Miura. In Press, Calalysis Reviews.

15. Pretreatment Chemistry in the Preparation of Silica-Supported $\mathrm{Pt}, \mathrm{Ru}$, andPt-Ru Catalysts: An In-Situ UV Diffuse Reflectance Study. With W.Zou, J. Catal. 133, 202 (1992).

16. Bimetallic Pt-Ru Silica Supported Catalysts: Preparation Implications onStructure and Catalytic Actirity: With G. del Angel, V.Bertin, P.Bosch, R.Gomez. Nowrewa 

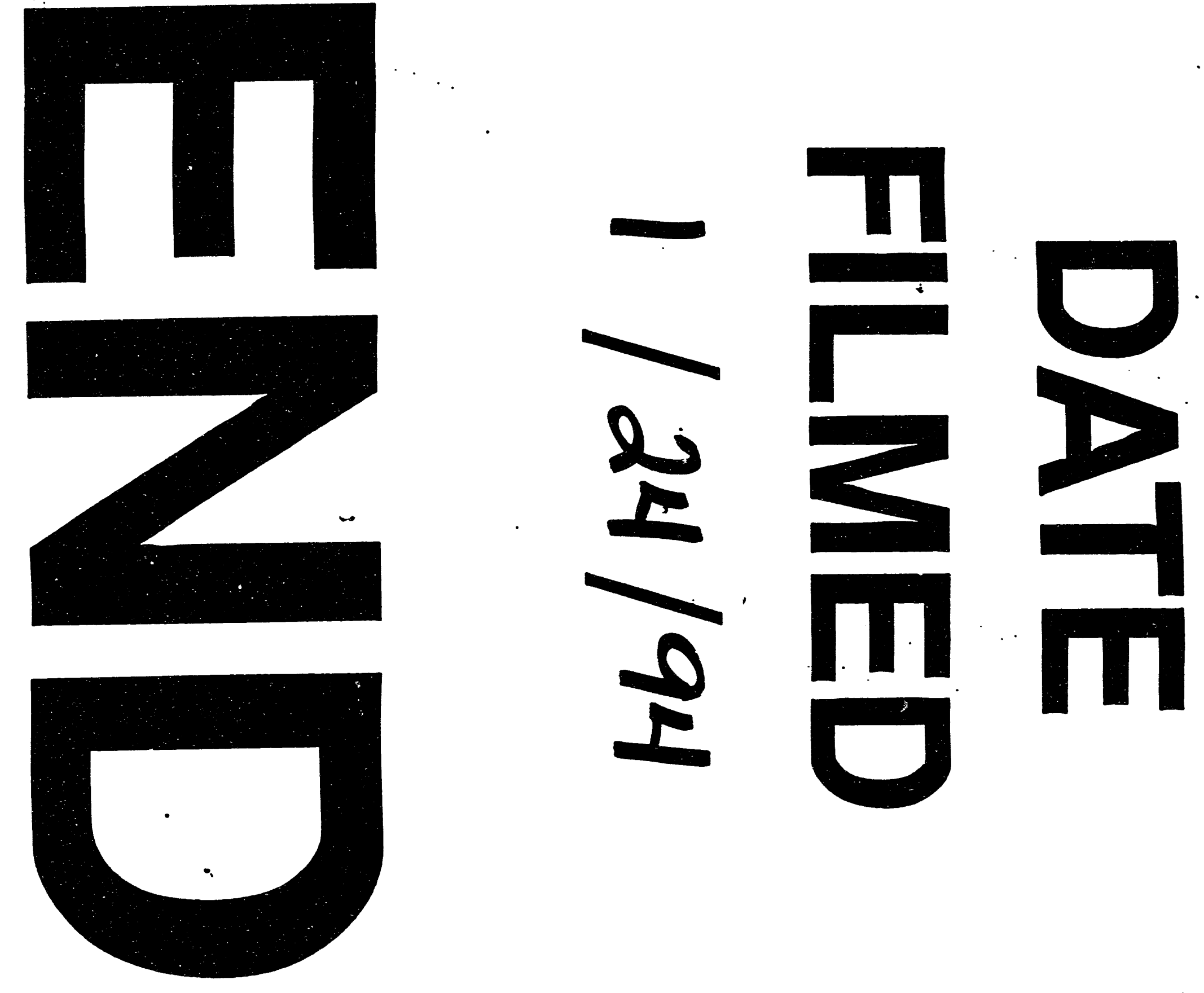
